Article

\title{
Germacrene D, A Common Sesquiterpene in the Genus Bursera (Burseraceae)
}

\author{
Koji Noge $^{1, \dagger * *}$ and Judith X. Becerra ${ }^{2}$
}

1 Department of Entomology, University of Arizona, Tucson, AZ 85721, USA

2 Department of Biosphere 2, University of Arizona, Tucson, AZ 85721, USA;

E-Mail: jxb@email.arizona.edu (J.X.B.)

† Present address: Department of Biological Production, Akita Prefectural University, Akita 0100195, Japan.

* Author to whom correspondence should be addressed; E-Mail: noge@akita-pu.ac.jp.

Received: 12 November 2009; in revised form: 15 December 2009 / Accepted: 15 December 2009 / Published: 15 December 2009

\begin{abstract}
The volatile components of the leaves of five Bursera species, B. copallifera, $B$. exselsa, B. mirandae, B. ruticola and B. fagaroides var. purpusii were determined by gas chromatography-mass spectrometry (GC-MS). Germacrene D was one of the predominant components (15.1-56.2\%) of all of these species. Germacrene D has also been found in other Bursera species and some species of Commiphora, the sister group of Bursera, suggesting that the production of germacrene D might be an ancient trait in the genus Bursera.
\end{abstract}

Keywords: Bursera; burseraceae; germacrene D; monoterpenes; sesquiterpenes

\section{Introduction}

The genus Bursera (Burseraceae) comprises approximately 100 species with a geographical distribution extending from the southwestern United States to Peru. The genus predominates in the tropical dry forests of Mexico where about 85 species coexist and about 75 of them are endemic [1-3]. The genus Bursera is divided into two sections, Bullockia and Bursera. Bursera release their resins when they are attacked by their herbivore, Blepharida beetles (Chrysomelidae: Alticinae) [4,5]. The 
resin is reported to decrease the survival and growth of Blepharida beetles [5,6]. The chemical analysis of the leaf components of B. biflora and B. schlechtendalii revealed that their resins consisted mostly of mono- and sesquiterpenes, and alkanes [7,8].

The volatile chemistry of five species, B. copallifera, B. excelsa, B. mirandae, B. ruticola (belonging to section Bullockia) and B. fagaroides var. purpusii (from section Bursera), were analyzed in this study. Bursera copallifera is native to the dry forests from the state of Nayarit to Oaxaca and Puebla at altitudes of between 1,000 and 1,900 m. Bursera excelsa is mostly found along the Pacific coast at low altitudes, while $B$. mirandae has a narrow distribution in the north of the states of Guerrero and Oaxaca. Bursera ruticola is a narrow endemic form the tip of Baja California. Bursera fagaroides var. purpusii is an abundant species also of relative wide distribution in the South of Mexico at altitudes between 300 and $900 \mathrm{~m}$. All of these species are abundant either locally or regionally. Yet, little information is known about their chemistry.

\section{Results and Discussion}

The components found in the five Bursera species analyzed are summarized in Table 1. Since the chemical profiles of the field samples were very similar to those of the greenhouse plants, only the latter ones are presented. The similarity of the chemical profiles between field and greenhouse samples suggests that the production of these compounds is quite stable even in the face of environmental changes. The chemical profiles of each one of these species were species-specific. For example, some compounds such as $\alpha$-thujene, $\alpha$-phellandrene, $\beta$-ocimene, and others were detected in only one of the species. Some compounds such as $\alpha$-pinene, $\beta$-caryophyllene, germacrene D and bicyclogermacrene, however, were detected in all of the species examined as either major (higher than $10 \%$ of total) or minor (less than $10 \%$ of total) components. The ratio of monoterpenes to sesquiterpenes was also different among the species (Table 1). The composition pattern could be classified into three types; (1) monoterpene-rich group (B. fagaroides var. purpusii), (2) sesquiterpene-rich group (B. copallifera and B. excelsa), and (3) the intermediate group (both monoterpene- and sesquiterpene-rich; $B$. mirandae and $B$. ruticola). It seems that terpene production in the species of the section Bursera tends to be biased toward monoterpenes, and a high percentage of these compounds have been found in the leaves of other species belonging to this section such as B. lancifolia, B. rezedowskii, B. schlechtendalii and B. morelensis (75-95\%) [6].

Germacrene D was one of the predominant components found in the leaves of the five species analyzed in this study (15.1-56.2\%; Table 1). The concentration of germacrene D was $0.14 \pm 0.02 \mathrm{mg}$ per gram of fresh leaves (mg/g.1., means $\pm \mathrm{SD}, \mathrm{N}=5$ ) in B. copallifera, $0.14 \pm 0.03 \mathrm{mg} / \mathrm{g} .1$. in $B$. excelsa, $0.12 \pm 0.03 \mathrm{mg} / \mathrm{g} .1$. in B. mirandae, $1.06 \pm 0.33 \mathrm{mg} / \mathrm{g} .1$. in B. ruticola and $0.13 \pm 0.06 \mathrm{mg} / \mathrm{g} .1$. in $B$. fagaroides var. purpusii, respectively. A preliminary chemical screening of the leaves of 26 other Bursera species also revealed the presence of germacrene D in all of them $(2.6-53.8 \%$, data not shown), suggesting that this compound is common in the genus. Germacrene D has been recently reported from the leaves of B. simaruba [9] and the stem of B. graveolens [10], respectively. Germacrene D has also been found in some species of Commiphora, the sister group of Bursera, such as C. africana (Noge and Becerra, unpublished), C. holtziana [11] and C. myrrha [12]. Thus, producing germacrene D might be an ancient trait in the genus Bursera. 
Table 1. Composition in the leaf of five Bursera species.

\begin{tabular}{|c|c|c|c|c|c|c|c|}
\hline \multirow[b]{2}{*}{ Compound } & \multirow[b]{2}{*}{$t_{\mathrm{R}}(\min )^{a}$} & \multirow[b]{2}{*}{$\mathrm{ID}^{b}$} & \multicolumn{5}{|c|}{ Composition (\%) } \\
\hline & & & $\begin{array}{c}\text { B. } \\
\text { copallifera }\end{array}$ & B. excelsa & B. mirandae & B. ruticola & $\begin{array}{l}\text { B. fagaroides } \\
\text { var. purpusii }\end{array}$ \\
\hline$\alpha$-Thujene & 7.65 & 2 & 0.2 & - & - & 5.3 & - \\
\hline$\alpha$-Pinene & 7.81 & 1 & 0.7 & 1.6 & 6.6 & 10.3 & 67.8 \\
\hline Camphene & 8.15 & 2 & - & - & - & 1.2 & 1.2 \\
\hline Sabinene & 8.53 & 2 & - & - & - & 2.8 & 1.2 \\
\hline$\beta$-Pinene & 8.65 & 1 & - & 4.7 & - & 21.9 & 5.7 \\
\hline$\beta$-Myrcene & 8.76 & 1 & - & - & 0.5 & - & 2.0 \\
\hline$\alpha$-Phellandrene & 9.13 & 1 & 0.3 & 1.2 & 15.0 & - & - \\
\hline$p$-Cymene & 9.44 & 1 & - & - & 0.6 & - & - \\
\hline Limonene & 9.52 & 1 & - & - & - & 0.4 & 0.9 \\
\hline$\beta$-Phellandrene & 9.56 & 1 & - & - & 1.9 & 2.0 & 0.2 \\
\hline$\beta$-Ocimene & 9.75 & 1 & - & 4.9 & - & - & - \\
\hline Sesquiterpene & 14.21 & 3 & - & 2.6 & - & - & - \\
\hline$\alpha$-Copaene & 14.80 & 1 & 1.7 & - & 2.7 & - & - \\
\hline Sesquiterpene & 14.94 & 3 & 1.7 & 6.4 & 0.7 & 0.5 & - \\
\hline$\beta$-Caryophyllene & 15.43 & 1 & 9.6 & 15.0 & 14.4 & 18.3 & 4.3 \\
\hline$\alpha$-Humulene & 15.88 & 1 & 12.5 & 0.7 & 0.5 & 0.6 & - \\
\hline Sesquiterpene & 15.93 & 3 & 0.4 & - & 0.5 & - & - \\
\hline Sesquiterpene & 16.05 & 3 & 1.5 & 0.7 & - & - & - \\
\hline Germacrene D & 16.18 & 1 & 56.2 & 50.5 & 36.6 & 31.9 & 15.1 \\
\hline Bicyclogermacrene & 16.36 & 2 & 6.2 & 8.8 & 1.2 & 0.7 & 0.8 \\
\hline Sesquiterpene & 16.55 & 3 & 2.4 & - & - & 1.2 & - \\
\hline Sesquiterpene & 16.57 & 3 & - & 1.5 & 2.7 & - & - \\
\hline Sesquiterpene & 17.33 & 3 & 1.0 & 1.3 & - & 0.6 & - \\
\hline Sesquiterpene & 18.06 & 3 & 1.4 & - & - & 0.5 & - \\
\hline Sesquiterpene & 18.27 & 3 & - & - & - & 1.0 & - \\
\hline Unknown & 25.95 & 4 & - & - & 2.6 & - & - \\
\hline Unknown & 26.58 & 4 & - & - & - & 0.9 & - \\
\hline Monoterpenes & & & 1.2 & 12.4 & 24.6 & 43.9 & 79.0 \\
\hline Sesquiterpenes & & & 94.6 & 87.5 & 59.3 & 55.3 & 20.2 \\
\hline
\end{tabular}

${ }^{a}$ Retention times are based on GC-FID analysis with DB-5MS capillary column; ${ }^{b}$ Method of identification: 1, matching GC retention time and mass spectrum with an authentic standard; 2, mass spectral matching with a library spectrum; 3, interpretation of the mass spectrum; 4, unidentified; ${ }^{c}$ Percentages are based on GC peak area. Percentages higher than $10 \%$ are bolded. - , Not detected.

Germacrene D has been found not only in angiosperms and gymnosperms but also in bryophites (Table 2), yet despite its wide distribution, its biological function in plants is still not well understood. It has been proposed that germacrene D plays a role as a precursor of various sesquiterpenes such as cadinenes and selinenes [13,14]. Plant terpenes have often been reported as anti-herbivore defenses [15]. It has also been suggested that germacrene D, by itself may have deterrent effects against 
herbivores and it has been reported to have insecticidal activity against mosquitoes [16], as well as repellent activity against aphids [17] and ticks [11].

Bursera is attacked by a group of specialized chrysomelid beetles, the genus Blepharida. These beetles show a preference for colonizing chemically similar plants that are not necessarily phylogenetically close [18]. This preference for chemically similar plants might impose pressures on plants to develop divergent chemical components. Thus, the common presence of germacrene D in Bursera may be advantageous as a source of other terpenes that could make the plants chemically different and thus help them escape from herbivory by unadapted Blepharida beetles. We are currently investigating its potential role against Bursera's herbivores. Being such an abundant and frequent compound in this genus, it is likely to play an interesting role in the functioning of these plants.

Table 2. Examples of the presence of germacrene D in plants.

\begin{tabular}{|c|c|c|c|}
\hline Plant group & Plant species & Family & Reference \\
\hline \multicolumn{4}{|c|}{ Spermatophytes } \\
\hline \multicolumn{4}{|l|}{ Angiosperms } \\
\hline \multirow[t]{29}{*}{ Eudicots } & Bursera copallifera & Burseraceae & This study \\
\hline & Bursera excelsa & Burseraceae & This study \\
\hline & Bursera mirandae & Burseraceae & This study \\
\hline & Bursera ruticola & Burseraceae & This study \\
\hline & Bursera fagaroides var. purpusii & Burseraceae & This study \\
\hline & Bursera graveolens & Burseraceae & {$[10]$} \\
\hline & Bursera simaruba & Burseraceae & [9] \\
\hline & Boswellia sacra & Burseraceae & [19] \\
\hline & Commiphora Africana & Burseraceae & Noge and Becerra, Unpublished \\
\hline & Commiphora holtziana & Burseraceae & {$[11]$} \\
\hline & Commiphora myrrha & Burseraceae & {$[12]$} \\
\hline & Protium icicariba & Burseraceae & {$[20]$} \\
\hline & Eucalyptus dunnii & Myrtaceae & {$[21]$} \\
\hline & Eugenia uniflora & Myrtaceae & {$[22]$} \\
\hline & Citrus natsudaidai & Rutaceae & {$[23]$} \\
\hline & Chloroxylon swieetenia & Rutaceae & {$[16]$} \\
\hline & Zanthoxylum rhoifolium & Rutaceae & {$[24]$} \\
\hline & Zanthoxylum setulosum & Rutaceae & {$[24]$} \\
\hline & Angelica glauca & Apiaceae & {$[25]$} \\
\hline & Torilis japonica & Apiaceae & {$[26]$} \\
\hline & Altemisia annua & Asteraceae & {$[27]$} \\
\hline & Brickellia veronicaefolia & Asteraceae & {$[28]$} \\
\hline & Solidago altissima & Asteraceae & [29] \\
\hline & Solidago Canadensis & Asteraceae & {$[30]$} \\
\hline & Hemizygia petiolata & Lamiaceae & {$[17]$} \\
\hline & Phlomis chimerae & Lamiaceae & {$[31]$} \\
\hline & Phlomis grandiflora var. grandiflora & Lamiaceae & {$[31]$} \\
\hline & Phlomis leucophracta & Lamiaceae & {$[31]$} \\
\hline & Stachys germanica & Lamiaceae & {$[32]$} \\
\hline
\end{tabular}


Table 2. Cont.

\begin{tabular}{llll}
\hline \multirow{4}{*}{ Monocots } & Stachys iva & Lamiaceae & {$[32]$} \\
& Lycopersicon hirsutum & Solanaceae & {$[33]$} \\
& Amomum subulatum & Zingiberaceae & {$[34]$} \\
\multirow{4}{*}{ Magnoliids } & Curcuma rhizomes & Zingiberaceae & {$[35]$} \\
& Cananga odorata & Annonaceae & {$[36]$} \\
& Cryptocarya mandioccana & Lauraceae & {$[14]$} \\
Gymnosperms & Talauma ovata & Magnoliaceae & {$[37]$} \\
& Piper lanceaefolium & Piperaceae & {$[38]$} \\
& Araucaria bidwillii & Araucariaceae & {$[39]$} \\
& Araucaria heterophylla & Araucariaceae & {$[39]$} \\
& Pinus radiate & Pinaceae & {$[40]$} \\
& Halocarpus bidwillii & Podocarpaceae & {$[41]$} \\
& Podcarpus spicatus & Podocarpaceae & {$[42]$} \\
\hline
\end{tabular}

The genus Bursera is one of the dominant members of the tropical dry forests of Mexico in terms of both diversity and abundance. This study is a contribution to the chemical knowledge of this important group of plants.

\section{Experimental}

\subsection{Plant materials}

Samples of leaves of one to five mature individuals from each species were collected from natural field populations and immediately extracted in dichloromethane. We also collected cuttings of each species and rooted them in a mixture of $70 \%$ pumice and 30\% topsoil. All cuttings took and were kept in a greenhouse at the University of Arizona under similar environmental conditions to those in the field. When these cuttings developed leaves, they were also extracted for chemical analysis. Voucher specimens of all except for B. ruticola are deposited at the University of Arizona Herbarium (ARIZ) and the Mexican National Herbarium at the Autonomous National University of Mexico (MEXU) [2]. Voucher specimen of B. ruticola is deposited at ARIZ [3].

\subsection{Sample preparation}

Fresh leaf materials were collected from greenhouse plants (B. copallifera, 47-64 mg; B. excelsa, 42-141 mg; B. mirandae, 23-33 mg; B. ruticola, 35-74 mg; B. fagaroides var. purpusii, 35-52 mg) and immediately extracted for $24 \mathrm{~h}$ at $4{ }^{\circ} \mathrm{C}$ with $1 \mathrm{ml}$ of dichloromethane containing $10 \mathrm{ng} / \mu \mathrm{l}$ anisole as an internal standard. The extracts were then collected into a new glass vial and kept at $4{ }^{\circ} \mathrm{C}$ until chemical analysis.

\subsection{Chemical analysis}

One microliter of each extract was analyzed by GC-MS (an Agilent 6890N gas chromatograph linked to an Agilent 5975B mass spectrometer, operated at $70 \mathrm{eV}$, with a HP-5MS capillary column, 
$30 \mathrm{~m} \times 0.25 \mathrm{~mm}$ i.d., $0.25 \mu \mathrm{m}$ in film thickness) and GC (the same gas chromatograph as GC-MS with a flame ionization detector, with a DB-5MS capillary column, $25 \mathrm{~m} \times 0.32 \mathrm{~mm}$ i.d., $0.52 \mu \mathrm{m}$ in film thickness). The oven temperature was programmed from $50{ }^{\circ} \mathrm{C}\left(3 \mathrm{~min}\right.$ holding) to $290{ }^{\circ} \mathrm{C}$ at a rate of $10{ }^{\circ} \mathrm{C} / \mathrm{min}$ and then held for $5 \mathrm{~min}$. The injector temperature was maintained at $200{ }^{\circ} \mathrm{C}$. When the authentic standard of germacrene $\mathrm{D}$ was analyzed with the injector temperature at $250{ }^{\circ} \mathrm{C}$, some artificial peaks were observed. However, none of these peaks were detected when the injector was maintained at $200{ }^{\circ} \mathrm{C}$. The analyses were replicated five times using different leaves for each species. The same analyses were performed on the leaf extractions collected in the field.

Quantification analysis of germacrene D from greenhouse plants was performed with selected ion monitoring (SIM) using the ions $\mathrm{m} / \mathrm{z} 161$ (quantification ion) and $\mathrm{m} / \mathrm{z}$ 91(qualifier ion). The mass spectrum of germacrene D is summarized as follows: $m / z(\%) 204\left(\mathrm{M}^{+}, 17\right), 162(14), 161$ (100), 133 (18), 120 (21), 119 (32), 105 (51), 93 (20), 91 (42), 81 (27), 79 (26), 77 (21), 67 (10), 55 (11), 41 (18). The ions $\mathrm{m} / \mathrm{z} 108$ and 78 were used as qualification and qualifier ions for the internal standard (anisole), respectively. The ratio of peak area of qualification ion of germacrene D to internal standard was calculated. The concentration was determined by comparing the peak area ratio in the sample with those found in the calibration standard $(2-85 \mathrm{ng} / \mu \mathrm{L})$.

\section{Conclusions}

The GC-MS analysis of the leaf extract of five Bursera revealed that they produce species-specific chemical components in their leaves. The study also shows the presence of germacrene D as a common sesquiterpene in the genus.

\section{Acknowledgements}

We thank D. Lawrence Venable (University of Arizona) for critical reading of the manuscript. We are also grateful to Leif Abrell and Brenda Jackson (University of Arizona) for the generous gift of chemicals. This work was supported by National Science Foundation CAREER grant, a Young Investigator award from the Beckman Foundation, and a grant from the Vice President for Research and the Colleges of Science and Agriculture of the University of Arizona to J.X.B.

\section{References}

1. Rzedowski, J.; Kruse, H. Algunas tendencias evolutiv as en Bursera (Burseraceae). Taxon 1979, 28, 103-116.

2. Becerra, J.X.; Venable, D.L. Nuclear ribosomal DNA phylogeny and ITS implication for evolutionary trends in Mexican Bursera (Burseraceae). Am. J. Bot. 1999, 86, 1047-1057.

3. Becerra, J.X. Evolution of Mexican Bursera (Burseraceae) inferred from ITS, ETS, and 5S nuclear ribosomal DNA sequences. Mol. Phyl. Evol. 2003, 26, 300-309.

4. Becerra, J.X.; Venable, D.L. Rapid-terpene-bath and "squirt-gun" defense in Bursera schlechtendalii and the counterploy of chrysomelid beetles. Biotropica 1990, 22, 320-323.

5. Becerra, J.X. Squirt-gun defense in Bursera and the Chrysomelid counterploy. Ecology 1994, 75, 1991-1996. 
6. Becerra, J.X.; Venable, D.L.; Evans, P.H.; Bowers, W.S. Interactions between chemical and mechanical defenses in the plant genus Bursera and their implications for herbivores. Amer. Zool. 2001, 41, 865-876.

7. Evans, P.H.; Becerra, J.X.; Venable, D.L.; Bowers, W.S. Chemical analysis of squirt-gun defense in Bursera and counterdefense by chrysomelid beetles. J. Chem. Ecol. 2000, 26, 745-754.

8. Evans, P.H.; Becerra, J.X. Non-terpenoid essential oils from Bursera chemapodicta. Flavour Fragr. J. 2006, 21, 616-618.

9. Sylvestre, M.; Longtin, A.P.A.; Legault, J. Volatile leaf constituents and anticancer activity of Bursera simaruba (L.) Sarg. essential oil. Nat. Prod. Commun. 2007, 2, 1273-1276.

10. Young, D.G.; Chao, S.; Casabiana, H.; Bertrand, M.C.; Minga, D. Essential oil of Bursera graveolens (Kunth) Triana et Planch from Ecuador. J. Essent. Oil Res. 2007, 19, 525-526.

11. Birkett, M.A.; Al Abassi, S.; Krober, T.; Chamberlain, K.; Hooper, A.M.; Guerin, P.M.; Pettersson, J.; Pickett, J.A.; Slade, R.; Wadhams, L.J. Antiectoparasitic activity of the gum resin, gum haggar, from the East Africa plant, Commiphora holtziana. Phytochemistry 2008, 69, 1710-1715.

12. Marongiu, B.; Piras, A.; Porcedda, S.; Scorciapino, A. Chemical composition of the essential oil and supercritical $\mathrm{CO}_{2}$ extract of Commiphora myrrha (Nees) Engl. and of Acorus calamus L. J. Agric. Food Chem. 2005, 53, 7939-7943.

13. Bülow, N.; König, W.A. The role of germacrene D as a precursor in sesquiterpene biosynthesis: Investigation of acid catalyzed, photochemically and thermally induced rearrangements. Phytochemistry 2000, 55, 141-168.

14. Telascrea, M.; de Araújo, C.C.; Marques, M.O.M.; Facanali, R.; de Moraes, P.L.R.; Cavalheiro, A.J. Essential oil leaves of Cryptocarya mandioccana Meisner (Lauraceae): Composition and intraspecific chemical variability. Biochem. Syst. Ecol. 2007, 35, 222-232.

15. Langenheim, J.H. Higher plant terpenoids: A phytocentric overview of their ecological roles. $J$. Chem. Ecol. 1994, 20, 1223-1280.

16. Kiran, S.R.; Devi, P.S. Evaluation of mosquitocidal activity of essential oil and sesquiterpenes from leaves of Chloroxylon swietenia DC. Parasitol. Res. 2007, 101, 413-418.

17. Bruce, T.J.A.; Birkett, M.A.; Blande, J.; Hooper, A.M.; Martin, J.L.; Khambay, B.; Prosser, I.; Smart, L.E.; Wadhams, L.J. Response of economically important aphids to components of Hemizygia petiolata essential oil. Pest Manag. Sci. 2005, 61, 1115-1121.

18. Becerra, J.X. Insects on plants: Macroevolutionary chemical trends in host use. Science 1997, 276, 253-256.

19. Al-Harrasi, A.; Al-Saidi, S. Phytochemical analysis of the essential oil from botanically certified oleogum resin of Boswellia sacra (Omani Luban). Molecules 2008, 13, 2181-2189.

20. Siani, A.C.; Garrido, I.S.; Monteiro, S.S.; Carvalho, E.S.; Ramos, M.F.S. Protium icicariba as a source of volatile essences. Biochem. Syst. Ecol. 2004, 32, 477-489.

21. Zini, C.A.; Zanin, K.D.; Christensen, E.; Caramão, E.B.; Pawliszyn, J. Solid-phase microextraction of volatile compounds from the chopped leaves of three species of Eucalyptus. $J$. Agric. Food Chem. 2003, 51, 2679-2686. 
22. Melo, R.M.; Corrêa, V.F.S.; Amorim, A.C.L.; Miranda, A.L.P.; Rezende, C.M. Identification of impact aroma compounds in Eugenia uniflora L. (Brazilian pitanga) leaf essential oil. J. Braz. Chem. Soc. 2007, 18, 179-183.

23. Phi, N.T.L.; Nishiyama, C.; Choi, H.-S.; Sawamura, M. Evaluation of characteristic aroma compounds of Citrus matsudaidai Hayata (Natsudaidai) cold-pressed peel oil. Biosci. Biotechnol. Biochem. 2006, 70, 1832-1838.

24. Boehme, A.K.; Noletto, J.A.; Haber, W.A.; Setzer, W.N. Bioactivity and chemical composition of the leaf essential oils of Zanthoxylum rhoifolium and Zanthoxylum setulosum from Monteverde, Costa Rica. Nat. Prod. Res. 2008, 22, 31-36.

25. Agnihotri, V.K.; Thappa, R.K.; Meena, B.; Kapahi, B.K.; Saxena, R.K.; Qazi, G.N.; Agarwal, S.G. Essential oil composition of aerial parts of Angelica glauca growing wild in North-West Himalaya (India). Phytochemistry 2004, 65, 2411-2413.

26. Itokawa, H.; Matsumoto, H.; Mihashi, S. Isolation of oppositane- and cycloeudesmane-type sesquiterpenoids from Torilis japonica D.C. Chem. Lett. 1983, 1253-1256.

27. Tellez, M.R.; Canel, C.; Rimando, A.M.; Duke, S. O. Differential accumulation of isoprenoids in glanded and glandless Artemisia annua L. Phytochemistry 1999, 52, 1035-1040.

28. Rivero-Cruz, B.; Rivero-Cruz, I.; Rodríguez, J.M.; Cerda-García-Rojas, C.M.; Mata, R. Qualitative and quantitative analysis of the active components of the essential oil from Brickellia veronicaefolia by nuclear magnetic resonance spectroscopy. J. Nat. Prod. 2006, 69, 1172-1176.

29. Niwa, M.; Iguchi, M.; Yamamura, S. Co-occurence of $(-)$ and (+)-germacrene-D in Solidago altissima L.: Determination of the optical rotation of optically pure germacrene-D. Chem. Pharm. Bull. 1980, 28, 997-999.

30. König, W.A.; Bülow, N.; Saritas, Y. Identification of sesquiterpene hydrocarbons by gas phase analytical methods. Flavour Fragr. J. 1999, 14, 367-378.

31. Celik, S.; Gokturk, R.S.; Flamini, G.; Cioni, P.L.; Morelli, I. Essential oils of Phlomis leucophracta, Phlomis chimerae and Phlomis grandiflora from Turkey. Biochem. Syst. Ecol. 2005, 33, 617-623.

32. Radulović, N.; Lazarević, J.; Ristić, N.; Palić, R. Chemotaxonomic significance of the volatiles in the genus Stachys (Lamiaceae): Essential oil composition of four Balkan Stachys species. Biochem. Syst. Ecol. 2007, 35, 196-208.

33. van der Hoeven, R.S.; Monforte, A.J.; Breeden, D.; Tanksley, S.D.; Steffens, J.C. Genetic control and evolution of sesquiterpene biosynthesis in Lycopersicon esculentum and L. hirsutum. Plant Cell 2000, 12, 2283-2294.

34. Naik, J.P.; Rao, L.J.M.; Kumar, T.M.M.; Sampathu, S.R. Chemical composition of the volatile oil from the pericarp (husk) of large cardamon (Amomum subulatum Roxb.). Flavour Fragr. J. 2004, 19, 441-444.

35. Yang, F.Q.; Li, S.P.; Chen, Y.; Lao, S.C.; Wang, Y.T.; Dong, T.T.X.; Tsim, K.W.K. Identification and quantitation of eleven sesquiterpenes in three species of Curcuma rhizomes by pressurized liquid extraction and gas chromatography-mass spectrometry. J. Pharm. Biomed. Anal. 2005, 39, 552-558. 
36. Stashenko, E.E.; Prada, N.Q.; Martínez, J.R. HRGC/FID/NPD and HRGC/MSD study of Colombian ylang-ylang (Cananga odorata) oils obtained by different extraction techniques. $J$. High Resol. Chromatogr. 1996, 19, 353-358.

37. Stefanello, M.E.A.; Salvador, M.J.; Ito, I.Y.; Wisniewski, A.; Simionatto, E.L.; de Mello-Silva, R. Chemical composition, seasonal variation and evaluation of antimicrobial activity of essential oils of Talauma ovata A. St. Hil. (Magnoliaceae). J. Essent. Oil Res. 2008, 20, 565-569.

38. Mundina, M.; Vila, R.; Tomi, F.; Tomàs, X.; Cicció, J.F.; Adzet, T.; Casanova, J.; Cañigueral, S. Composition and chemical polymorphism of the essential oils from Piper lanceaefolium. Biochem. Syst. Ecol. 2001, 29, 739-748.

39. Pietsch, M.; König, W.A. Enantiomers of sesquiterpene and diterpene hydrocarbons in Araucaria species. Phytochem. Anal. 2000, 11, 99-105.

40. Cool, L.; Zavarin, E. Terpene variability of mainland Pinus radiata. Biochem. Syst. Ecol. 1992, 20, 133-144.

41. Hayman, A.R.; Weavers, R.T. Terpenes of foliage oils from Halocarpus bidwillii. Phytochemistry 1990, 29, 3157-3162.

42. Lorimer, S.D.; Weavers, R.T. Foliage sesquiterpenes and diterpenes of Podocarpus spicatus. Phytochemistry 1987, 26, 3207-3215.

43. König, W.A.; Bülow, N.; Fricke, C.; Melching, S.; Rieck, A.; Muhle, H. The sesquiterpene constituents of the liverwort Preissia quadrata. Phytochemistry 1996, 43, 629-633.

Sample Availability: Available from the author (J.X.B.).

(C) 2009 by the authors; licensee Molecular Diversity Preservation International, Basel, Switzerland. This article is an open-access article distributed under the terms and conditions of the Creative Commons Attribution license (http://creativecommons.org/licenses/by/3.0/). 